\title{
Corporate Criminal Responsibility in China: Legislations and Its Deficiency*
}

\author{
Yingjun Zhang
}

Law School, South-Central University for Nationalities, Wuhan, China.

Email: zyj2161@sina.com

Received May $15^{\text {th }}$, 2012; revised June $15^{\text {th }}, 2012$; accepted June $26^{\text {th }}, 2012$

\begin{abstract}
The Chinese corporate criminal responsibility is featured by the "Double Punishments" imposed both on the Unit who commit a crime and the persons who are directly in charge. As an attributable liability, corporate criminal responsibility requires more precise and detailed principles of attribution in the national criminal law. Unfortunately, it has not archived yet in Chinese Criminal Law. As well, at current, only one kind of monetary penalty, the fine, can be imposed on the Unit who commit a crime. It is far from enough to prevent corporate offences. On enumerating and analyzing Chinese criminal legislations concerning corporate criminal responsibility, the author finds the main deficiency in it and recommend on how to perfect it.
\end{abstract}

Keywords: Corporate Responsibility; Corporate Crimes; Chinese Criminal Legislations and Deficiencies

\section{Introduction}

Since the establishment of People's Republic of China in October, 1949, it is not a long history in Chinese legal system to criminalize the corporate crimes committed by legal persons. Because it was the planned economy instead of free market that predominated in China before the Reform and Opening-up policies applied in 1978. As a result, the legal persons or legal entities were not allowed to operate independently in free market as a legitimate civil subject which has the legal capacities to enter into the relations with the other civil subjects for its own interests and take responsibility by its own assets. On the contrary, the corporations, the enterprise and the other kind of legal entities were all state-owned, only can act as the subordinate to the State and for the interest of the State. Consequently, there were no corporate crimes at that time. That's why there were no provisions for corporate crimes in the 1979 Code of Criminal Law of P. R. China.

With the economic reform and opening-up in China, the state-owned enterprises and units began to separate gradually. Meanwhile, with the existence of allowed private economic sectors, more and more private capital shifted into the market. As a result, the private companies, foreign joint ventures and wholly owned companies,

\footnotetext{
"This article is one of the research results of the Project sponsored by The Ministry of Education of P. R. China on "The Legal Issues on the Control of the Crimes Committed by Transnational Companies” (No. 11JJD820014).
}

shareholding companies, limited liability companies, social organizations and other economic forms of organization emerged. However, the crimes or offences committed by legal entities also increases. In view of this, the new Criminal Law of P. R. China, revised at 1997 (Hereinafter China 1997 Criminal Law) extends the jurisdiction over the corporate crimes. However, according to Chinese legislations, the "legal persons" is generally limited to the organization with certain qualifications, including an independent property and limited liability, the scope of which is smaller than the "organization" or "Unit". In China, the term of "Organization" or "Unit" has more broad meaning. The "Organization" generally means any kind of entities, groups especially those in private sectors which are organized loosely, whereas the term of "Unit" includes not only any companies, enterprises, institutions and organizations, but also some entities in public sector, such as the state organ which is the organ of state authorities or administrations. It seems that the "Unit" is more suitable for the true situation in China because in some circumstance, the state organ can be criminal subject, although there are some debates on this point. That is why in the Chapter IV of "General Provisions" in China 1997 Criminal Law, it is titled as "The Crimes committed by a Unit" instead of corporate crimes. For this reason, in China, we use "Crimes committed by Unit" refer to the "corporate crimes".

In spite of establishment of the corporate criminal responsibility in the Chinese criminal law, there are a num- 
ber of administrative acts and regulations providing the corporate administrative responsibility for their wrongdoings. Those regulations expressly authorize the competent Administrations to take administrative measures to impose the sanctions-including fine- on the corporations and the other legal entities for their violations and wrong-doings. If the legal persons not only violate the administrative regulations but also the criminal law, they shall be subject to criminal sanctions, and criminal liability.

\section{The Legislations with Respect to the Corporate Criminal Responsibility in China}

In China, in addition to some clauses in the "General Provisions" and "Specific Provisions" of China 1997 Criminal Law and its amendments, the legislations with respect to Corporate criminal responsibility also consist of the valid judicial interpretations mainly from the Chinese Supreme Court which can be viewed as the sources of law and also the legislations. As for the corporate criminal responsibility, up to now, those judicial interpretations include the "Supreme Court interpretation on the specific issues related to the application of criminal law in hearing criminal cases involving crimes committed by units” (Supreme Court Interpretation No. 17/1999) and the "Supreme Court interpretation on the question of whether or not, in hearing the cases of crimes committed by a unit, should distinguish principal criminal or the accomplice between the persons who are directly in charge and the other persons who are directly responsible for the crime" (Supreme Court Interpretation No. 31/ 2000).

As a principal reference for judges in hearing the criminal cases, the explanatory documents from Supreme Court play a very important role in practice, although they are not the source of law and not binding in China. Regarding the corporate criminal responsibility, we can find the "Explanatory document from the research institution of Supreme Court on the issues related to the application of law in hearing the criminal cases involving the crimes committed by the foreign companies, enterprises and institutions within the territory of P. R. China".

In order to give the outline of how is the corporate criminal responsibility established in the legal system of China, I will introduce those provisions at first, and then, conclude the main characteristics and deficiencies.

\subsection{Provisions in the Criminal Law of People's Republic of China}

In the "General Provisions" of the Criminal Law of the People's Republic of China, there is a specific section for the criminalization of the corporate crimes-that is, the Section 4 "Crimes Committed by a Unit," -which consists of Article 30 and Article 31.They provide as follows:

Article 30 Any company, enterprise, institution, State organ, or organization that commits an act that endangers society, which is prescribed by law as a crime committed by a unit, shall bear criminal responsibility. Article 31 Where a unit commits a crime, it shall be fined, and the persons who are directly in charge and the other persons who are directly responsible for the crime shall be given criminal punishment. Where it is otherwise provided for in the Specific Provisions of this Law or in other laws, those provisions shall prevail.

In the "Specific Provisions" of the Criminal Law of P. R. China, after 8 amendments, the number of the counts of crimes which can be committed by a unit, increases to 124. According to the latest Amendment VIII to the Criminal Law of P. R. China, they mainly can be found in the Chapter III "Crimes of Disrupting the Order of the Socialist Market Economy"1 and the Chapter VI "Crimes of Obstructing the Administration of Public Order" ${ }^{2}$ as well as several individual Articles. ${ }^{3}$

\subsection{Corporate Criminal Responsibility in the Judicial Interpretations}

As mentioned above, the legislations of corporate criminal responsibility also include the relevant judicial interpretations. At current, they consist of two interpretation documents from Chinese Supreme Court: the Supreme Court Interpretation No. 17/1999 and Supreme Court Interpretation No. 31/2000. They provide some detailed criteria about how to judge the corporate crimes in the application of law.

The provisions concerned in "Supreme Court interpretation on the specific issues related to the application of criminal law in hearing criminal cases involving crimes committed by units" (Supreme Court Interpretation No. 17/1999).

The Supreme Court of P. R. China interpreted as follows:

1) The "companies, enterprises and institutions" provided in Article 30 of the China 1997 Criminal Law, include not only state-owned, collectively owned compa-

\footnotetext{
${ }^{1}$ The Chapter III in the Part Two "Specific Provisions" of the Criminal Law of P. R. China consists of 8 Sections, from Article 140 to Article 231 a, which includes 110 counts of crimes. Most of them can be committed by Unit.

${ }^{2}$ The Chapter VI in the Part Two "Specific Provisions" of the Criminal Law of P. R. China consists of 9 Sections, from Article 277 to Article 367 , which include 120 counts of crimes. Only some of them can be committed by Unit.

${ }^{3}$ Two counts of the crimes committed by a unit added by The lasted Amendment VIII to the Criminal Law of P. R. China, are contained in Article 276(a) and Article 205(a).
} 
nies, enterprises, public institutions, but also legallyestablished joint ventures, cooperative enterprises as well as those private or wholly-owned companies, enterprises and institutions which are qualified as legal persons.

2) The crimes committed by those companies, enterprises and institutions which were established by individuals to commit the crime, or the companies, enterprises, institutions which commit crimes as the main activities since their establishment, shall not be criminalized as the crimes committed by unit.

3) If the individuals commit a crime falsely in the name of the unit and distribute the proceeds from this crime under the table, shall be criminalized as the crime committed by natural persons and punished in accordance with the Criminal Law [1].

The provisions concerned in the "Supreme Court [1] interpretation on the question of whether or not, in hearing the cases of crimes committed by a unit, the persons who are directly in charge and the other persons who are directly responsible for the crime should be distinguished between principal criminal and the accomplice." (Supreme Court Interpretation No. 31/2000).

In this document, the Supreme Court gave the following interpreted opinion on the question concerned:

In hearing the cases of the crimes committed by a unit, shall condemn the persons who are directly in charge and the other persons who are directly responsible for the crime separately, in accordance with their role in committing the crimes, don't have to distinguish between principal criminal and the accomplice [2].

Corporate Criminal Responsibility in the "Explanatory document from the research institution of Supreme Court on the issues related to the application of law in hearing the criminal cases involving the crimes committed by the foreign companies, enterprises and institutions within the territory of P. R. China”.

As mentioned above, the explanatory documents play a very important part in judicial practice in China. It is also true in hearing the cases concerning the corporate crimes. In this document, the Supreme Court holds that:

Within the territory of $P$. R. China, the foreign companies, enterprises and institutions which can be quailfied as the Legal Persons in accordance with the Chinese law, commit the offences of endangering society which can be criminalized as a crime according to the Criminal Law of China, shall be held the corporate criminal responsibility in the light of the provisions of the crimes committed by a unit in the Criminal Law of China.

The crimes committed by the foreign companies, enterprises and institutions which were established by individuals to commit crimes or offences within the territory of P. R. China, or, since the establishment, the foreign companies, enterprises and institutions have committed crimes within the territory of P. R. China as their main activities, shall not be criminalized as the crimes committed by unit [3].

\section{The Types of Corporate Crimes in the Criminal Law of China}

The "Specific Provisions" of the Criminal Law of P. R. China, provides 124 counts of crimes which can be committed by Unit. We can divide them into two types: the Single Crimes Committed by a Unit, and Non-Single Crimes Committed by a Unit [4].

\subsection{The Single Crimes Committed by a Unit}

In the criminal law of P. R. China, the Single Crimes Committed by a Unit refers to the crime which only can be committed by unit, other than natural persons. That means, only the unit can be the criminal subject of those kinds of crimes. For example, the crimes established in Article 327 of the Criminal Law of P. R. China which reads that "Where a State-owned museum, library or other institution sells or presents as gifts without permission any cultural relics in its collection, which is under State protection, to any non-State-owned institution or individual, it shall be fined, and the persons who are directly in charge and the other persons who are directly responsible for the offence shall be sentenced to fixedterm imprisonment of not more than three years or criminal detention."

\subsection{Non-Single Crimes Committed by a Unit}

Non-Single Crimes Committed by a Unit refers to the crimes can be committed by unit and also individuals, namely, the natural persons. In the "Specific Provisions" of the Criminal Law of China, most of the crimes committed by unit are Non-Single Crimes Committed by a Unit. In these cases, for those natural persons who committed these crimes, some clauses provide the same punishments as imposed on the persons who are directly in charge or directly responsible for the crimes committed by a unit. For example, Article 187 provides that:

Any employee of a bank, ..., shall be sentenced to fixedterm imprisonment of not more than five years or criminal detention and shall also be fined...; if especially heavy losses are caused, he shall be sentenced to fixed-term imprisonment of not less than five years and shall also be fined... Where a unit commits the crime mentioned in the preceding paragraph, it shall be fined, and the persons who are directly in charge and the other persons who are directly responsible for the crime shall be punished according to the provisions in the preceding paragraph.

Whereas, the other provisions impose the heavier punishment on those natural persons who commit those 
crimes. For example, Article 191 provides the natural persons, whoever commits the crimes of money-laundering, "...; if the circumstances are serious, he shall be sentenced to fixed-term imprisonment of not less than five but not more than 10 years...", but "Where a unit commits any of the crimes mentioned in the preceding paragraph, ...the persons who are directly in charge and the other persons who are directly responsible for the crime shall be sentenced to fixed-term imprisonment of not more than five years... [5]."

\section{The Characteristics of Corporate Criminal Responsibility in China}

From the provisions listed above, we can conclude the following characteristics of corporate criminal responsibility in Chinese criminal law:

\subsection{The Criminal Subject}

The criminal subjects of corporate crimes, the Unit, includes any company, enterprise, institution, State organ, or organization, according to the Article 30 of the "General Provisions” in China 1997 Criminal Law.

This provision, however, arise some debates which mainly focus on the conception of a "Unit" and the question of whether the state organ can be the criminal subject of the crimes committed by unit [6] and whether the company established by individuals can be the subject of the crimes committed by a Unit [7].

Because of no defining the conception of the term of "Unit" who commit a crime in Chinese Criminal Law, in practice, it is ambiguous to decide which entities can be criminalized as a Unit who commit crime, such as the branch of a company with legal personality.

As for whether the state organ can be the criminal subject of the crimes committed by unit, most scholars hold that, the state organ cannot be the criminal subject of corporate crimes. The main reasons depend on that the state organ is the organ of state which is be subordinate to the state and function as a public actor on behalf of the state, without any possession of the property or funds on which that state organ can bear its responsibility independently. Consequently, if the state organ can be the criminal subject of the corporate crimes and sentenced to the monetary penalty, it is in fact a self-punishment. To some extent, it is true, in my opinion, but it is also necessary to prescribe the state organ as the criminal subject of the crimes committed by unit. Because in practice, it actually exists that the state organs commit the crimes in the name of that organ.

Regarding the private company established by individuals, some people hold that they cannot be criminalized as the Unit who committed crime on the ground of that those kind of companies are owned by individuals, the natural person, the offences committed by that company finally should be deemed to be the offences committed by that natural person, the owner. In my opinion, however, although the private companies are actually owned by natural persons, but the assets of that company is independent of the private property of that owner [8]. They are different actors in performing the economic activities. So, we should differentiate the behavior of the companies from the action of their owner. They should be responsible for their behavior separately. For this reason, if the offence is committed by the company-on behalf of it and for the benefit of it-this offence should be criminalized as the offence committed by a Unit.

\subsection{Double Punishment-Based Responsibility}

In Chinese criminal law, the corporate criminal responsebility is featured by the "Double Punishments" imposed both on the Unit who commit a crime and the persons who are directly in charge and responsible for the crime. The Article 31 of China 1997 Criminal Law establishes this style responsibility for corporate crimes and also provides the related penalties. For the Unit who commit a crime, should be fine; for the persons who are directly in charge and the other persons who are directly responsible for the crime shall be given criminal punishment, including the monetary penalty and imprisonment. Accordingly, at current, only one kind of monetary penalty, the fine, can be imposed on the Unit who commit a crime, whereas the other penalties such as disclosure of the companies, suspending from some business operations, exclusion from participation in a procurement, all can be imposed as the administrative sanctions by the authorities according to administrative regulations.

However, the exception clause also contained in this Article which can be found in the following sentence, "...Where it is otherwise provided for in the Specific Provisions of this Law or in other laws, those provisions shall prevail." This clause, in my opinion, on the one hand, indicates the possibility in some circumstance for providing the single punishment only on the Unit who commit a crime, or the persons who are directly in charge or directly responsible for the crime. On the other hand, it leaves the space for developing new penalties in the future except for the single monetary penalty currently imposed on the Unit who commit a crime.

\section{The Deficiency in the Legislations Concerning Corporate Criminal Responsibility}

After analyzing the legislations about the corporate criminal responsibility in China, I put some questions on which the Chinese Criminal Law keep silent. From another perspective, it reflects the defects existed in our 
criminal law.

\subsection{Whose Act Can Be Attributable to the Unit Who Be Defined to Commit a Crime?}

For this question, we can conclude from the wording in Article 31 of China 1997 Criminal Law that the conduct from the persons who are directly in charge and the other persons who are directly responsible for the crime can be attributable to the Unit. However, the question is which kind of people should be defined as the "persons who are directly in charge" and "the other persons who are directly responsible for the crime", the legal representative, the officials in management, the owner, or the persons who actually control the company, enterprise and the other private organization, or the persons in common position but acting on behalf of the unit and for the benefit of this unit?

As we see, the provisions in Chinese Criminal Law keep silent on this question. They are too basic to be used as the sufficient legal basis to define the crimes committed by a Unit, but those cases actually happen in practice, especially in the cases of the crimes committed by the persons in the giant companies which are organized complicatedly with the sophisticated structure.

\subsection{Which Kind of Conduct Can Be Defined as the Crimes Committed by a Unit?}

Although our code of Criminal Law keeps silent in this point, we can find the indirect answer in the judicial interpretations and documents from Supreme Court, such as the "Supreme Court Interpretation on the Specific Issues Related to the Application of Criminal Law in Hearing Criminal Cases Involving Crimes Committed by Units” (Supreme Court Interpretation No. 17/1999). In the Paragraph 3, it provides that "If the individuals commit a crime falsely in the name of the unit and distribute the proceeds from this crime under the table, shall be criminalized as the crime committed by natural persons and punished in accordance with the Criminal Law", which seems indicate if act on behalf of the unit and the illegally obtained proceeds owned by that unit, should be defined as the crimes committed by a unit. Furthermore, It is clarified in the "Supreme Court Minutes of a Panel Discussion on the Legal Issues in Hearing the Cases Concerning Financial Crimes" that "if act on behalf of the unit and the illegally obtained proceeds owned by that unit, should be defined as the crimes committed by a unit” [9].

With the judicial interpretations and the Supreme Court documents mentioned above, it seems to come to this conclusion: if an act would be attributable to the crimes committed by a Unit, it should be acting on behalf of the Unit, the proceeds which illegally obtained from that act should be owned by that unit [10]. In my opinion, it reveals a more detailed principle of attribution to the crimes committed by a unit-the corporate crimes in China, but it is debatable for the following reasons:

First, who can act on the behalf of the Unit, the officials of management in the Unit or the common employee? And which kind of act can be regarded as the act on behalf of the Unit, the act on their duty or the employ's act should meet some requirements so as to let the Unit know? They are very important to decide the corporate crimes [11], but as mentioned above, our criminal legislations and interpretations keep silent.

Second, on the wording and context of Chinese law, "the proceeds illegally obtained from that act" generally means those visible proceeds which are obtained from the crimes directly or indirectly. It is true for some cases of the crimes committed by unit, such as the Unit commit the crimes of money-laundering, the unit commit the crimes of acceptance of bribes. However, in practice, in some cases of the crimes committed by a unit, the unit actually benefits from that crime, but that benefit may not always be visible proceeds. Sometimes, they are invisible interests, for example, through those illegal activities to improve social status and the reputation of that unit, or secure a competitive advantage and the business opportunities. Those interests maybe turn into the real visible proceeds in the future. However, at current, if charge the unit commit a crime, possibly it couldn't meet the requirement of "the illegally obtained proceeds owned by that unit” because the interests derived from that crime and benefit that unit maybe not yet turn into the money, the assets and the other kind of visible proceeds. For this reason, comparing with "the illegally obtained proceeds owned by that unit", "for benefit of that unit" seems to be a more appropriate requirement for defining the cases of the crimes committed by a unit.

\section{Conclusions}

As mentioned above, through the detailed enumeration and in-depth analysis of the Chinese criminal legislation on the crimes committed by a Unit, we can see the trend of that the number of the counts of corporate crime is growing, but the provisions are very simple and basic as follows:

Firstly, As an attributable liability, corporate criminal responsibility requires more precise and detailed provisions in criminal law, including the criminal subject, mens rea requirements and the principles of attribution. Unfortunately, however, it has not been archived yet in Chinese Criminal Law. As a result, this is the one of the reasons why in practice, the offences prosecuted as the crimes committed by Unit is less than actually existed in China. 
Secondly, the penalty for corporate crimes is very simple. Only fine can be imposed on the wrongfully-doing corporations. It is far from enough to prevent corporate offences. Thirdly, the criminal legislations of the crimes committed by Unit are complemented largely by judicial interpretations, the explanatory documents and the other kind of documents like Minutes. Those documents are less authoritative than national criminal law. This is not good to prosecute and try corporation offences.

In order to ensure the impartiality in trial and fight against corporate crimes effectively, I suggest to take following actions to remedy the deficiencies in Chinese Criminal Law:

First of all, make the detailed uniform provision in Chinese Code of Criminal Law which should precisely define the criminal subject of the crime committed by Unit, the mens rea requirements of that crime and the principle of attribution.

Second, add the other penalties such as disclosure of the companies, suspending from some business operations, excluding from participation in procurement and the measures to enforce the company to change their internal structure to establish self-control system [12]. Although in China, due to a large number of administrative single acts regulating the corporate offences in addition to criminal law, those penalties can be imposed by different responsible authorities on the wrongfully-doing corporations as an administrative sanction. However, because those administrative regulations are single and disperse that there is no uniform administrative regulation providing the uniform requirements on the corporate offences, different authority has different understanding on how to judge the corporate offences. As a result, some wrongfully-committed corporations go beyond the arm of the law.

For this reason, the detailed uniform provisions of corporate crimes in Chinese Code of Criminal Law surely become an important guide and reference for administrative authorities in their practice to investigate corporate offences. That's why I recommend to perfect the related provisions in Chinese Criminal Law.

As well, with the economic development in China, the number of legal entities is growing. Consequently, the corporate offences become more and more, the structure of modern corporation become more complicate. They pose the threat to stability of societies and security of economies, challenging the justice and fairness. In order to fight against transnational crimes, the Chinese government adopted some international conventions contained the responsibility of legal persons and then take the obligation to implement them in Chinese law. So, it is necessary and significant to do something for the research on the Chinese legislation concerning corporate offences, making them more equitable and perfect.

\section{REFERENCES}

[1] Supreme Court of P. R. China, "Supreme Court of P. R. China Interpretation on the Specific Issues Related to the Application of Criminal Law in Hearing Criminal Cases Involving Crimes Committed by Units,” Supreme Court Interpretation No. 14/1999, China, Adopted at 18 June 1999. http://www.law-lib.com/law/law_view.asp?id=460

[2] Supreme Court of P. R. China, "Supreme Court of P. R. China Interpretation on the Question of Whether or Not, in Hearing the Cases of Crimes Committed by a Unit, the Persons Who Are Directly in Charge and the Other Persons Who Are Directly Responsible for the Crime Should Be Distinguished between Principal Criminal and the Accomplice,” Supreme Court Interpretation No. 31/2000, China, Adopted at 28 September 2000.

http://www.lawtime.cn/info/xingfa/fzdwfz/201102141116 29.html

[3] "Explanatory Document from the Research Institution of Supreme Court of China on the Issues Related to the Application of Law in Hearing the Criminal Cases Involving the Crimes Committed by the Foreign Companies, Enterprises and Institutions within the Territory of P. R. China," 2003. http://china.findlaw.cn/fagui/xf/23/26369.html

[4] X. L. Chen, "Analysis on the Crime Committed by Unit: From the Perspective of Chinese Criminal Law," Journal of Henan Administrative Institute of Politics and Law (Chinese), Vol. 76, No. 1, 2003, pp. 15-22.

[5] “Criminal Law of the People's Republic of China (English Text Officially), Article 187, Article191, from the Official Website of The National People's Congress of the People’s Republic of China,” 1997.

http://law.npc.gov.cn:87/page/browseotherlaw.cbs?rid=en \&bs $=97956 \&$ anchor $=0 \#$ go0

[6] W. Zhang and A. Y. Jia, "On Unit Crime," Journal of Peking University (Humanities and Social Science), Vol. 38, No. 3, 2001, pp. 132-139.

[7] Z. X. Zhou, "Research on Some Issues of the Crimes Committed by Unit," Journal of East China University of Political and Science (Chinese), Vol. 2, No. 1, 1999, pp. 3-9.

[8] R. Jin, "Research on the Crimes Committed by Unit," Criminal Research (Chinese), No. 4, 2008, pp. 66-73.

[9] J. G. Sun, "Some Thinking about Understanding and Application of the 'Supreme Court Interpretation on the Specific Issues Related To the Application of Criminal Law in Hearing Criminal Cases Involving Crimes Committed by a Unit' (Chinese)," Reference to Criminal Trial (Chinese), Vol. 3, No. 3, 1999, pp. 34-36.

[10] J. Zhang, W. Jiang, S. Lang and X. L. Chen, “Talks on Criminal Law (General Principle),” Law Press, Beijing, 2002, pp. 293-295.

[11] L. Shi, "Analysis on the Requirement of the Unit Crime: 'On Behalf of the Unit' and 'for the Benefit of the Unit'," People's Procuratorial Semimonthly (Chinese), Vol. 7, No. 1, 2005, pp. 37-39.

[12] H. Li, "Thinking of How to Perfect the Penalty System of Chinese Criminal Law," Studies in Law and Business (Chinese), Vol. 141, No. 1, 2011, pp. 80-87. 